\title{
Cooperatives: An Efficient Alternative Toward Comprehensive Waste Management
}

\author{
Izarelly Rosillo Pantoja \\ Universidad Autónoma de Querétaro, Santiago de Querétaro, Mexico
}

\begin{abstract}
To protect the right to a healthy environment is the obligation of all Mexican authorities. Therefore, it is necessary to guarantee, protect, and if necessary repair the damage to said fundamental right. National development policy should be comprehensive and sustainable, and—as stated in the Mexican Constitution—-the state should make sure this is so. Environmental damages in Mexico reflect the necessity of mitigating the environmental exhaustion and degradation that both diminish the Mexican natural heritage and endanger the health of its inhabitants. In environmental matters, it is imperative to implement comprehensive waste management in an efficient manner, as waste increment is subject to patterns of production, consumption, and population growth. The informal sector in waste management is directly exposed to contaminants; the cost of recycling is disproportional to its profitability and it does not contribute to national productivity. It is necessary to consolidate actions in the way of diminishing these problems. The constitution of cooperatives for comprehensive waste management allows for the formalization of this sector, inclusive social policy, as well as for improving the model of development and application of human rights established by the Supreme Court. In a nutshell, cooperatives are a win-win path toward comprehensive waste management. This study looks at the legal and technical foundations that may justify the creation of cooperatives as a tool for mitigating environmental impacts, protecting human rights, and bolstering sustainable development.
\end{abstract}

Keywords: cooperatives, Mexico, waste

Public involvement is of utmost importance to protect the rule of law in a democratic system. A democracy used to be defined merely by its citizens' votes, but nowadays citizen participation is indispensable if a democratic state wants to become institutionally strong. Over time, a changing society incorporated unmissable elements to a democratic society: access to public information and citizen participation. As political science experts have pointed out, this work as a system of checks and balances that avoids power abuses. Building this system was not easy, but it is now a reality protected by the constitution.

In environmental matters, the relevance of citizen participation has been clear in the sorting of waste according to the origin of its valuable materials. It is important to recall, analyze, and recognize the efforts made in different states of the republic. Each state has advanced in waste sorting under different circumstances.

Corresponding author: Izarelly Rosillo Pantoja, Bachelor of Laws, MA in State and Municipal Public Administration, Ph.D. candidate in law, Universidad Autónoma de Querétaro, Mexico, exercised several functions in private companies as manager and legal director, and teaches at Universidad Autónoma de Querétaro, advisor in environmental law, litigation attorney and technical secretary at Querétaro's Network for Handling Waste (REQMAR, A.C.); research fields: constitutional, notarial law, and Amparo. E-mail: izarellyrosillo@msn.com; irosillo@enlaw.net. 
In all of them, an active and engaging society has fought different obstacles. The role of institutions is to incentivize the constitution of cooperatives as a tool for self-sustainability. It is these societies that should be allowed to participate in public contests for public services related to adequate waste management. This would truly generate sustainable economic growth, a goal expressed in numeral 25 of the Mexican Constitution.

\section{Sustainable Development and the Constitution}

Every legal system is born with each country's constitution. All regulatory provisions that materialize themselves in a state's actions emerge from this document. This is also the case in environmental matters. Numeral 25 of the Mexican Constitution points out the actions the state should follow to guarantee national development: "employment; fair distribution of income and wealth, social co-responsibility, citizen participation, social equality, productivity, sustainable development, expansion of the economic activity (cooperatives)" (emphasis added) ${ }^{1}$.

Numeral 23 enlists several elements the Constituent Assembly considered necessary to guarantee a comprehensive and sustainable economic growth. All of these elements should be taken into account in the National Planning Policies. This is why governmental institutions have a fundamental role in accomplishing the objectives set out in the National Plan of Development for the years 2013-2018. According to the constitution, cooperatives are one of the instruments that should be made use of in the National Development Policies. These may foster the multiplication of initiatives of citizen organization and participation in the whole country, as well as a reduction of the extreme poverty that prevails in the country. It is cooperatives that could accomplish the "Social Development for an Inclusive Mexico" set out in the National Plan of Development, increasing formal employment and productivity².

The National Council for the Evaluation of Social Development Policies (CONEVAL) ${ }^{3}$, in its study of poverty in Mexico, states that, in the years 2012-2014:

(1) The percentage of population in poverty increased from $45.5 \%$ to $46.2 \%$. The percentage of population in extreme poverty decreased from $9.8 \%$ to $9.5 \%$;

(2) The number of people in poverty increased from 53.3 to 55.3 millions. The number of people in extreme poverty decreased from 11.5 to 11.4 millions;

(3) The number of average social deficits (carencias promedio) of the population in poverty decreased from 2.4 to 2.3. The number of average social deficits of the population in extreme poverty decreased from 3.7 to 3.6 ;

\footnotetext{
1 “Article 25: It is the state's duty to guard national development and guarantee it is comprehensive and sustainable, that it strengthens the nation's sovereignty and its democratic regime, and that its competitiveness bolsters economic development, employment, and a fair distribution of income and wealth, allowing for a full exercise of the liberty and dignity of individuals, groups, and social classes. Competitiveness is to be understood as the set of conditions necessary for economic growth, promoting investment and generating employment. The state will look after the stability of public and private finance, in order to generate the conditions favorable to economic growth and employment. The National Development Plan and the state and municipal plans shall maintain this principle. The state will plan, conduct, coordinate, and guide national economic activity. And it will regulate and encourage activities demanded by the general interest, within the framework of the liberties protected by this constitution. The public, social, and private sectors will contribute-with social responsibility - to the national economic development, without lessening other forms of economic activity that contribute to the development of the Nation”. Mexican Constitution. Latest reform: DOF 10-07-2015. Consulted July 10, 2015 at http://www.diputados.gob.mx/ LeyesBiblio/htm/1.htm

2 Office of the President of the Republic, "Plan Nacional de Desarrollo 2013-2018", consulted July 20, 2015 at http://www.dof.gob.mx/nota_detalle.php?codigo=5299465\&fecha=20/05/2013.

3 CONEVAL is a decentralized organism of the Ministry of Social Development, in charge of evaluating Mexican social policy. CONEVAL was created in the General Law of Social Development of 2003, published on January 20, 2004.
} 
(4) The percentage of rural population in poverty decreased from $61.6 \%$ to $61.1 \%$. The percentage of urban population in poverty increased from $40.6 \%$ to $41.7 \%$;

(5) In 24 states, the percentage of the population in poverty or extreme poverty decreased. In eight states, this percentage increased;

(6) Both a decrease in homes' income and demographics were factors in the increase of poverty;

(7) The increase of the income and the decrease of social deficits in the poorest sector of the population (decile 1) were factors in the decrease of extreme poverty.

Environmental public policy should maintain close ties with policies of social development. A country's growth cannot be maintained without environmental protection, as the conservation of landscape heritage cannot happen without improvements in social welfare and an overcoming of poverty of the people who inhabit it. Close ties between environmental and development policies should contribute to a cohesive state policy for the short- and long-term. This idea is known as the principle of sustainability ${ }^{4}$.

\section{Environmental Impact in the Mexican Constitution}

The National Accounts System includes data retrieved from the National System of Economic and Ecological Accounts (SCEEM, in Spanish). This system comprises all of the country's ecological information, which includes the costs due to the exhaustion of natural resources and environmental degradation. It takes into account the following categories: (1) oil; (2) forest resources and changes in land-use rights; (3) water resources (groundwater); (4) land degradation; (5) water pollution; (6) soil pollution; and (7) air pollution ${ }^{5}$.

The first three categories show resource availability and its recent trends. This first block shows ranks of resource exhaustion, according to water, forest, and oil balances. The remaining categories show results on environmental degradation. They register general trends and not numbers at a specific point in time.

Using the results of the SCEEM studies for the years 1997-2002 and its preliminary update for 2012, one can estimate the Gross Domestic Ecological Product (GDEP), as well as the costs of the environmental exhaustion and degradation of the country. The results of both studies can be summarized as follows:

(1) In Mexico, natural resources have become degraded and exhausted;

(2) Environmental degradation and exhaustion of natural resources are originated by continued productive processes;

(3) The economic activities that have caused this revolve around the production, distribution, and consumption of materials.

The environmental impact for the years 2007-2012 was an average per year of $10.5 \%$ of the gross domestic product (GDP) at current prices. Only in 2002, the costs due to exhaustion and degradation reached $\$ 623,075$ million Mexican pesos (10\% of GDP). In this same year, the money used for prevention of environmental damage was of only 33,099 million pesos. This amounts to only $5 \%$ of degradation costs. This information was calculated using data from the Ministry of the Environment and Natural Resources (SEMARNAT, in Spanish), which manages Mexico’s environmental policy.

\footnotetext{
${ }^{4}$ Izarelly Rosillo Pantoja and P. J. Gutiérrez Yurrita, "Fundamento jurídico-administrativo para la metamorfosis de una zona metropolitana en una ciudad región”, v International Congress of Environmental and Territorial Studies, Guayana, 2010 (now in process of publication).

5 National Institute for Statistics and Geography, Sistema de Cuentas Nacionales de México: Cuentas económicas y ecológicas de México, 2006-2010, México, INEGI, 2012.
} 
After 2002, the budget for remediating degradation has duplicated, but population and environmental liabilities have also increased ${ }^{6}$. The preliminary study for 2012 shows that costs due to exhaustion and environmental degradation would amount 985,064 million pesos, whereas only 143,066 million would be used for environmental protection ${ }^{7}$. Only in 2002, the deficit between environmental degradation and money used to remediate it amounted 589,976 million pesos. In 2012, this deficit was of 841,998 million pesos. This reflects an alarming situation in matters of ecological economy for Mexico ${ }^{8}$ (see Figure 1).

\begin{tabular}{|c|c|c|c|c|c|c|c|c|}
\hline Año & PIB & $\begin{array}{c}\text { PIB } \\
\text { Ecológico } \\
\text { (PIBE) }\end{array}$ & $\begin{array}{c}\text { Costos totales } \\
\text { agor } \\
\text { degradación } \\
\text { ambiental } \\
\text { (CTADA) }\end{array}$ & $\begin{array}{c}\text { Gastos en } \\
\text { protección } \\
\text { ambiental } \\
\text { (GPA) }\end{array}$ & $\begin{array}{c}\text { PIBE/ } \\
\text { PIB }\end{array}$ & $\begin{array}{c}\text { CTADA/ } \\
\text { PIB }\end{array}$ & GPA/CTADA & $\begin{array}{c}\text { GPA/PIB } \\
\text { a } \\
\text { precios } \\
\text { básicos }^{1}\end{array}$ \\
\hline 2003 & $7,696,035$ & $7,043,365$ & 652,670 & 44,807 & 91.5 & 8.5 & 6.9 & 0.6 \\
\hline 2004 & $8,690,254$ & $7,986,018$ & 704,236 & 50,177 & 91.9 & 8.1 & 7.1 & 0.6 \\
\hline 2005 & $9,424,602$ & $8,667,688$ & 756,934 & 57,009 & 92.0 & 8.0 & 7.5 & 0.6 \\
\hline 2006 & $10,520,793$ & $9,722,967$ & 797,826 & 64,796 & 92.4 & 7.6 & 8.1 & 0.6 \\
\hline 2007 & $11,399,472$ & $10,544,785$ & 854,687 & 80,256 & 92.5 & 7.5 & 9.4 & 0.7 \\
\hline 2008 & $12,256,864$ & $11,338,259$ & 918,605 & 97,066 & 92.5 & 7.5 & 10.6 & 0.8 \\
\hline 2009 & $12,072,542$ & $11,235,677$ & 836,865 & 121,004 & 93.1 & 6.9 & 14.5 & 1.1 \\
\hline 2010 & $13,266,858$ & $12,380,590$ & 886,268 & 126,176 & 93.3 & 6.7 & 14.2 & 1.0 \\
\hline 2011 & $14,508,784$ & $13,559,399$ & 949,385 & 140,636 & 93.5 & 6.5 & 14.8 & 1.0 \\
\hline
\end{tabular}

Figure 1. Total costs due to environmental exhaustion and degradation (2003-2012). Source: National Institute for Statistics and Geography, System of Economic and Ecological Accounts (SCEEM).

Designing public policy aimed at diminishing environmental damage is of utmost importance. As we will see, cooperatives are a way of contributing to formal employment in matters of waste management.

\section{Comprehensive Waste Management and Its Relation to Cooperatives}

In Mexico, waste management depends on a series of political and administrative decisions: lack of budget and infrastructure, the constant turnover of civil servants, and change of policy stand in the way of appropriate

\footnotetext{
${ }^{6}$ National Institute for Statistics and Geography, Sistema de Cuentas Nacionales de México: Cuentas económicas y ecológicas de México, 2006-2010, México, INEGI, 2012. Consulted July 20, 2015 at http://www.inegi.org.mx/prod_serv/contenidos/ espanol/bvinegi/productos/derivada/economicas/medio\%20ambiente/2006-2010/SCEEM0610PS.pdf.

7 National Institute for Statistics and Geography, Sistema de Cuentas Nacionales de México: Cuentas económicas y ecológicas de México, informe preliminar 2012, México, INEGI, 2012. Consulted July 20, 2012 at http://www.inegi.org.mx/prod_ serv/contenidos/espanol/bvinegi/productos/derivada/economicas/medio_ambiente/MONOGRAFIA_SCEEM_2012.pdf.

${ }^{8}$ Izarelly Rosillo Pantoja, “Ética y justicia ambiental en el Estado constitucional mexicano", en Juan Ricardo Jiménez Gómez et al., Ética y justicia. Reflexiones y planteamientos intemporales, México, Porrúa, 2015.
} 
comprehensive waste management. Nowadays, waste management is a huge challenge for authorities, as it has remained unattended for years; it is a pending debt on government agenda.

So far, we have reviewed the flaws of environmental policy and the damages we are now facing. The implementation of cooperatives in waste management could not only bolster economic activity, but also sustainability. Furthermore, they could contribute to minimize health and environmental hazards. What should motivate citizens to get involved in this activity are its effects on improving social wellbeing. The goal of cooperatives would be to avoid wasteful practices, diminish the pollution of the environment and the sanitary issues caused by inappropriate waste management.

The Mayan cities of Mexico once developed a broad network of commercial activities based on the trade of everyday objects and luxury goods. The majority of the population was dedicated to producing goods under criteria for specialization, with division of labor by gender and skills. Calpullis and positos are examples of efficient cooperatives, which sometimes worked with barter. These activities were brought apart by the colonial institutions of New Spain, and the social groups that took part in them were harshly affected ${ }^{9}$.

After the Mexican Independence, cooperatives reemerged in the form of patron activities in favor of education, conducted mainly by high-society women. Afterwards, chambers of commerce and entrepreneurial associations copied the model and formalized it.

Incorporating cooperatives to environmental manage could bring waste management activities to the formal sector of the economy, thus improving concessions and service administration. Many already do the activities informally, as those involved in collecting waste, storage, recycling, waste recovery, and final disposition.

The General Law on Cooperatives (GLC) defines them as "a way of social organization integrated by legal persons based on common interests and the principles of solidarity, effort, and mutual help, with the purpose of satisfying individual and collective needs, by means of economic activities of production, distribution, and consumption of goods and services" (emphasis added) ${ }^{10}$.

Waste management cooperatives depend on citizen involvement, promotion by non-governmental organizations, support by academics, and governmental programs. They work under different types of approaches. Some are dedicated solely to one purpose — garbage classification, collection, or recycling. Others work with comprehensive management, generating or appropriating community projects. This is known as "empowering" ", and it allows projects to survive more than one municipal, state, or federal government term ${ }^{12}$.

Some citizen initiatives that already exist are: fashioning craftsmanship with waste, designing musical instruments with recoverable materials, building storage centers, creating school or community programs for separating and recovering materials. These activities face many hardships: travelling long distances, encountering opposition, scarce resources, advertising the project. In spite of this, creating cooperatives allows us to strengthen the national environmental and development policies, to protect human rights, and to guarantee wellbeing and law and order.

\footnotetext{
${ }^{9}$ G. Delgado de Cantú, Historia de México, México, Pearson-Prentice Hall, 2006, p. 58, p. 157, p. 340.

10 Cooperatives Law, latest reform: August 13, 2009 (translation by the author). Consulted July 20, 2015 at http://www.diputados.gob.mx/LeyesBiblio/pdf/143.pdf.

11 "Empowering" is the process through which people come to be conscious of their own interests and relate them to the interests of others, in order to acquire real decision-making power. To do this, people must be able to interact with their context, boost their access to power, and use it in different ways. The essence of empowerment is a mixture of psychological processes that prepare people to interact with their context, divided into three dimensions: (1) personal; (2) collective; and (3) inter-personal.

12 Cristina Cortinas de Nava, “La relevancia de la participación ciudadana”, symposyum RECICLA, Veracruz, 2009.
} 


\section{Cooperatives: Scope and Legal Status}

The first steps toward civil society organization were made in an informal fashion, i.e., without making use of legal instruments. Then, the mechanism came known as civil associations. This became the legal instrument for organizations to register and receive donations. Article 2570 of the Civil Code of the State of Querétaro defines associations as follows: "When several individuals have agreed to gather in a non-transitory manner, to accomplish a common goal, not forbidden by law and without economic character, they are constituting an association"13.

Civil associations are recognized by law to receive economic donations. However, they are restricted by law to access concessions or to conduct asset management, whereas cooperatives lack this restriction. According to Article 8 of the GLC, they can freely conduct any legal and economic activity ${ }^{14}$.

In Articles 21 and 30, the GLC classifies cooperatives as follows (see Table 1) ${ }^{15}$ :

Table 1

Classes and Categories of Cooperatives

\begin{tabular}{|c|c|}
\hline Classes of cooperatives & Categories of cooperatives \\
\hline $\begin{array}{l}\text { 1. Of consumers of goods and/or services. These are } \\
\text { cooperatives whose members associate with the purpose of } \\
\text { obtaining together goods and/or services for themselves, their } \\
\text { households, or their productive activities. } \\
\text { They may perform activities of supply and distribution, as well } \\
\text { as provide services related to education or housing. } \\
\text { 2. Of producers of goods and/or services. These are } \\
\text { cooperatives whose members associate with the purpose of } \\
\text { working together in the production of goods and/or services, } \\
\text { where each member contributes with physical or intellectual } \\
\text { work. Regardless of what kind of production they engage in, } \\
\text { these cooperatives may store, transport, and commercialize their } \\
\text { products, according to the GLC. } \\
\text { 3. Of savings and loans. These are cooperatives that focus on } \\
\text { savings (acquiring funding through the partners' savings } \\
\text { deposits) and loans (delivering resources obtained from the } \\
\text { same partners). }\end{array}$ & $\begin{array}{l}\text { 1. Ordinary. These are cooperatives that in order to function, } \\
\text { require only of their legal constitution. } \\
\text { 2. Of state participation. In this case, the state may grant } \\
\text { special-use permits for state-owned assets, according to the } \\
\text { respective laws. } \\
\text { These are cooperatives associated with federal, state, or } \\
\text { municipal authorities. They engage in the exploitation of } \\
\text { productive units or public services-mainly in administration, } \\
\text { or finance local, regional, or national economic development } \\
\text { projects. }\end{array}$ \\
\hline
\end{tabular}

Note. Source: made by the author.

According to the table, the most effective class of cooperatives for waste management would be that labeled "Producers of Goods or Services". These can be located both in the "Ordinary" classification and in the "State Participation" one, in case the state collaborates with the cooperative.

Those interested in constituting a cooperative for waste management should look into the following principles (see Table 2):

Cooperatives must be constituted before a public attester, who should then draft a Constitutive Act. According to the GLC, cooperatives of all kinds but "Savings and Loans" should have a minimum of five members to be constituted. Additional requirements are listed in Table $3^{16}$.

${ }^{13}$ Civil Code of the State of Querétaro, latest reform: May 22, 2015 (translation by author). Consulted July 28, 2015 at http://www.legislaturaqueretaro.gob.mx/repositorios/10.pdf.

14 General Law on Cooperatives, latest reform: August 13, 2009, Article 8.

15 General Law on Cooperatives, latest reform: August 13, 2009, Articles 21 and 30.

${ }^{16}$ General Law on Cooperatives, latest reform: August 13, 2009, Articles 11 and 12. 
Table 2

Legal Principles for Mandatory Surveillance in the Management of Cooperatives

Legal principles for mandatory surveilance in the management of cooperatives

Article 6. Cooperatives must supervise its management accords with the following principles:

(1) Freedom of association and voluntary withdrawal from the organization;

(2) Democratic management;

(3) Limited interest in some of the members' shares, if so agreed;

(4) Distribution of revenue proportionate to partners' participation;

(5) Promoting cooperative education and solidarity economy education;

(6) Participation in cooperative integration;

(7) Respect to the partners' individual right to belong to any political party or religious association, and promotion of an ecological culture ${ }^{17}$.

Note. Source: made by the author.

Table 3

Requirements to Form a Cooperative and Requirements of the General Assembly Act

\begin{tabular}{|l|l|}
\hline Requirements to form a cooperative & Requirements of the General Assembly Act \\
\hline $\begin{array}{l}\text { Article 11. The constitution of cooperatives must take into } \\
\text { account the following: }\end{array}$ & $\begin{array}{l}\text { Article 12. Cooperatives must be constituted in a partners' } \\
\text { general assembly, where an act must be drafted. The General } \\
\text { Assembly Act must include: }\end{array}$ \\
$\begin{array}{l}\text { (1) Each partner will have only one vote, regardless of his/her } \\
\text { contributions; } \\
\text { (2) They must be of variable capital; } \\
\text { (3) There will be an essential equality in the partners' rights and } \\
\text { obligations, and equal conditions for women; } \\
\text { (4) They will be of indefinite duration; } \\
\text { (5) They will be constituted with a minimum of five partners, } \\
\text { except those referred to in Article 33 bis. }\end{array} \mid \begin{array}{l}\text { (1) Theral information of the founding partners; } \\
\text { commissions; of those elected for the first councils and } \\
\text { (3) The basic constitution of the cooperative; } \\
\text { (4) Partners must credit their identity and ratify their will to } \\
\text { constitute the cooperative. The act will include the partners' } \\
\text { signatures and fingerprints, validated by a public notary, public } \\
\text { broker, district judge, first instance court judge, municipal } \\
\text { president, minister, or head of a politic or administrative body } \\
\text { of the Federal District, according to the place where the } \\
\text { cooperative is registered. }\end{array}$ \\
\hline
\end{tabular}

Note. Source: made by the author.

Annual yields must be shared among members according to the amount of work each partner carried out in the year. For this reason, it is very important that the Constitutive Act points out which activities will be conducted by each partner and how work will be evaluated. Law states this evaluation must take into account: (1) quality; (2) time; (3) technical expertise; and (4) level of education ${ }^{18}$.

It is important to point out what are the expectations on the quality of the service, the time each partner will dedicate to activities, and to credit the partners' technical expertise and level of education with official documents. Diplomas or certificates from courses or workshops taken in educational institutions or consulting firms are useful—if the institutions are renowned for their expertise or registered in the Ministry of Labor and Social Security.

For cooperatives to work efficiently, its management must be monitored thoroughly. Management must be divided in the following governing bodies (see Table 4):

\footnotetext{
${ }^{17}$ General Law on Cooperatives, latest reform: August 13, 2009, Article 6.

18 General Law on Cooperatives, latest reform: August 13, 2009, Article 28.
} 
Table 4

The Working and Management of Cooperatives

The functioning and management of cooperatives

Article 34. The management, administration, and internal surveillance of cooperatives will depend on the following governing bodies:

(1) The General Assembly;

(2) The Administrative Council;

(3) The Surveillance Council;

(4) The commissions and committees established by the GLC and all others designated by the General Assembly.

Notes. With respect to the use functioning and management of "Savings and Loans" cooperatives, see fraction 5, sections (a) to (d) of the GLC. Source: made by the author.

If cooperatives engaged in waste management wish to take in other functions-such as building a recycling plant-they must form a Technical Commission. This body should be run by technical personnel designated by the Administrative Council, and by a delegate from each of the productive units. The functions of the Technical Commission should be defined by the Constitutive Act ${ }^{19}$.

\section{Conclusions}

Cooperatives are an efficient and viable alternative for comprehensive waste management. If the Mexican government encouraged cooperatives, it would not only be complying with the General Law for the Prevention and Comprehensive Management of Waste, but it would be fulfilling its constitutional obligation to foster economic development and civil society participation. Furthermore, cooperatives will be a way of reaching the goals set out in the National Development Plan as to reducing public health risks and guaranteeing the human right to a healthy environment.

Environmental impacts reflect an opaque enforcement of environmental law, as well as an inefficient public policy toward the conservation of natural heritage. Relieving environmental impacts should be a priority for environmental authorities. Promoting and facilitating the formation of cooperatives could help in the accomplishment of this goal. In its compliance to the Mexican law, this strategy proves to be a win-win policy.

\section{References}

Civil Code of the State of Querétaro, latest reform. (2015). Retrieved from http://www.legislaturaqueretaro.gob.mx/repositorios/ 10.pdf

Constitution of the United States of Mexico. (1917). Retrieved from http://www.diputados.gob.mx/LeyesBiblio/pdf/1.pdf

Cooperatives Law, latest reform. (2009). Retrieved from http://www.diputados.gob.mx/LeyesBiblio/pdf/143.pdf

Cortinas de Nava, C. (2009). La relevancia de la participación ciudadana (The importance of public participation). Proceedings from the Symposium RECICLA. Veracruz.

Delgado de Cantú, G. (2006). Historia de México (Historyof Mexico). México: Pearson-Prentice Hall.

Gutiérrez Yurrita, P. (2007). Eco-Centrism vs. egocentrism: Socio-Ecology and human development. Environmental Law and Ecology, 3, 44-55.

Gutiérrez Yurritia, P., \& Rosillo Pantoja, I. (2009). A state ministry with future: The ministry for landscape heritage preservation and sustainability. Environmental Law and Ecology, 38-39(5), 55-78.

Gutiérrez Yurritia, P., \& Rosillo Pantoja, I. (2010). Fundamento jurídico-administrativo para la metamorfosis de una zona metropolitana en una ciudad región (Legal and administrative foundations for the metamorphosis of a metropolitan zone into a region-city). Proceedings from the 5th International Congress of Environmental and Territorial Studies. Guayana.

${ }^{19}$ General Law on Cooperatives, latest reform: August 13, 2009, Article 34. 
Leff, E. (2004). Environmental rationality: The social appropriation of nature. México: Siglo XXI.

Office of the President of the Republic. (2013). Plan Nacional de Desarrollo 2013-2018 (National Development Plan 2013-2018). Retrieved from http://www.dof.gob.mx/nota_detalle.php?codigo=5299465\&fecha=20/05/2013

Rabasa, E. (2007). The constitution and the environment. México: UNAM.

Rosillo Pantoja, I. (2015). Ethics and environmental justice in the mexican constitutional state. In J. R. Jiménez Gómez (Ed.), Ethics and justice. A temporary reflections and proposals. México: Porrúa. 